Provided for non-commercial research and education use. Not for reproduction, distribution or commercial use.

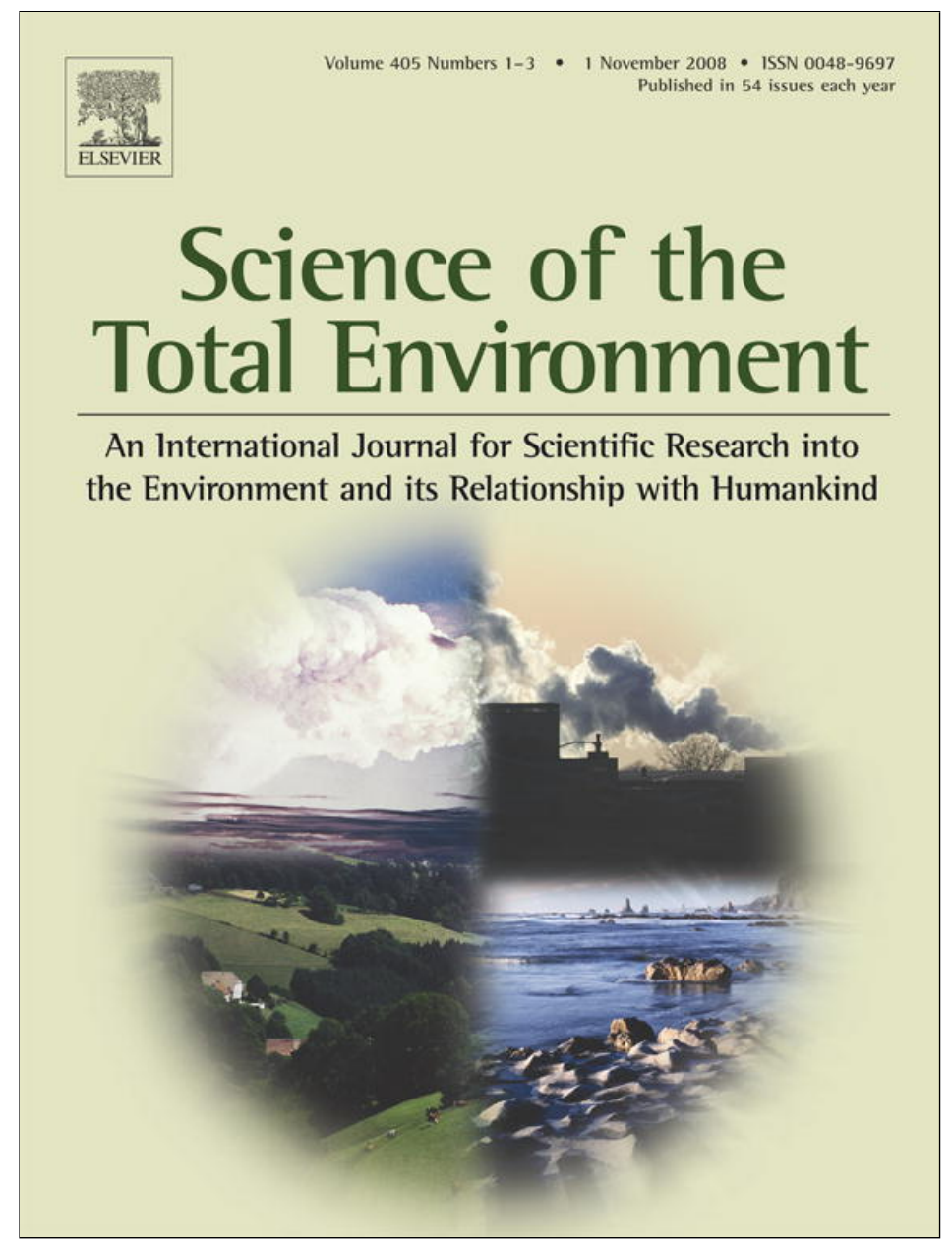

This article appeared in a journal published by Elsevier. The attached copy is furnished to the author for internal non-commercial research and education use, including for instruction at the authors institution and sharing with colleagues.

Other uses, including reproduction and distribution, or selling or licensing copies, or posting to personal, institutional or third party websites are prohibited.

In most cases authors are permitted to post their version of the article (e.g. in Word or Tex form) to their personal website or institutional repository. Authors requiring further information regarding Elsevier's archiving and manuscript policies are encouraged to visit:

http://www.elsevier.com/copyright 


\title{
Reproducing stone monument photosynthetic-based colonization under laboratory conditions
}

\author{
Ana Zélia Miller ${ }^{a, *}$, Leonila Laiz ${ }^{b}$, Juan Miguel Gonzalez ${ }^{b}$, Amélia Dionísioc, $^{c}$ \\ Maria Filomena Macedo ${ }^{a}$, Cesareo Saiz-Jimenez ${ }^{b}$ \\ ${ }^{a}$ Departamento de Conservação e Restauro, Faculdade de Ciências e Tecnologia, Universidade Nova de Lisboa, Monte de Caparica, \\ 2829-516 Caparica, Portugal \\ Instituto de Recursos Naturales y Agrobiologia, CSIC, Av. Reina Mercedes 10, 41012 Sevilla, Spain \\ 'Centro de Petrologia e Geoquímica, Instituto Superior Técnico, Av. Rovisco Pais, 1049-001, Lisboa, Portugal
}

\section{A R T I C L E I N F O}

Article history:

Received 13 December 2007

Received in revised form

26 June 2008

Accepted 28 June 2008

Available online 2 September 2008

\section{Keywords:}

Biodeterioration

Laboratory chamber

Limestone

Phototrophic microorganisms

Colonization experiment

\begin{abstract}
A B S T R A C T
In order to understand the biodeterioration process occurring on stone monuments, we analyzed the microbial communities involved in these processes and studied their ability to colonize stones under controlled laboratory experiments. In this study, a natural green biofilm from a limestone monument was cultivated, inoculated on stone probes of the same lithotype and incubated in a laboratory chamber. This incubation system, which exposes stone samples to intermittently sprinkling water, allowed the development of photosynthetic biofilms similar to those occurring on stone monuments. Denaturing gradient gel electrophoresis (DGGE) analysis was used to evaluate the major microbial components of the laboratory biofilms. Cyanobacteria, green microalgae, bacteria and fungi were identified by DNA-based molecular analysis targeting the $16 \mathrm{~S}$ and $18 \mathrm{~S}$ ribosomal RNA genes. The natural green biofilm was mainly composed by the Chlorophyta Chlorella, Stichococcus, and Trebouxia, and by Cyanobacteria belonging to the genera Leptolyngbya and Pleurocapsa. A number of bacteria belonging to Alphaproteobacteria, Bacteroidetes and Verrucomicrobia were identified, as well as fungi from the Ascomycota. The laboratory colonization experiment on stone probes showed a colonization pattern similar to that occurring on stone monuments. The methodology described in this paper allowed to reproduce a colonization equivalent to the natural biodeteriorating process.
\end{abstract}

(c) 2008 Elsevier B.V. All rights reserved.

\section{Introduction}

Stone monuments represent an important part of our world's cultural heritage. Natural stones are weathered by physical, chemical and biological factors. One of the most complex problems in monument conservation is to contrast biological deterioration or biodeterioration (Ortega-Calvo et al., 1995; Herrera et al., 2004; Miller et al., 2006). The interactions between environmental factors affecting stone monuments (e.g. light intensity, air pollution, humidity) and microorganisms are not well understood. Among the components of the microbial communities, phototrophic organisms are the primary producers and play an important role in the colonization and deterioration of stone monuments, causing extensive aesthetic, physical and chemical damages (Tomaselli et al., 2000; Ciferri, 2002; Crispim and Gaylarde, 2005). In order to understand the biodeterioration process, laboratory experiments present the advantage of controlling environmental variables which simplifies the answering of important questions. A number of different laboratory-based experimental biofilm model systems have been developed (Guillitte and Dreesen, 1995; Tiano et al., 1995; Tomaselli et al., 2000; Monte,

\footnotetext{
* Corresponding author. Tel./fax: +351 212948322 .

E-mail address: azm@fct.unl.pt (A.Z. Miller).
} 
2003; Prieto and Silva, 2005; Miller et al., 2006). In most cases, these systems were used to study single-species biofilms or a predefined mixed community, which cannot give a complete idea of the complex process involved in stone deterioration. In nature, microbes develop in more or less complex communities (Sand, 1997). Laboratory studies using natural microbial biofilms are scarce in biodeterioration studies.

The main goal of this work is the assessment of the ability of natural phototrophic communities colonizing stone probes under laboratory conditions.

\section{Materials and methods}

\subsection{Site description and environmental sampling}

Santa Clara-a-Velha Monastery is a gothic monument constructed in 1283, on the left bank of the Mondego River, with a yellowish, oolitic and dolomitic limestone of Sinemurian age (Aires-Barros et al., 2000), and a fine-grained compact and homogeneous limestone of Bathonian-Bajocian age - Ançã limestone - used for decorative architecture elements (Dionísio, 1997). Since the beginning of the 14th century, part of the monastery was buried by 5 to $7 \mathrm{~m}$ of alluvial sediments due to several river flooding occurrences. The monastery was abandoned in the 17th century, triggering a progressive deterioration process leading to a state of ruin. An exhaustive restoration campaign of Santa Clara-a-Velha Monastery started in 1995, entailing the removal of accumulated sediments in the cloister and in the church. It also included the construction of a peripheral water retention barrier. In June 2006, samples of a natural green biofilm, covering Ançã limestone columns of the Monastery's North façade, were collected at $50 \mathrm{~cm}$ above the ground, under aseptic conditions by scraping the biofilms into sterile tubes. Samples for culturing procedures were stored at $4{ }^{\circ} \mathrm{C}$ while those for nucleic acid analyses were preserved in the laboratory at $-80^{\circ} \mathrm{C}$ until being processed (samples AL1, AL2, and AL3).

\subsection{Experimental setup}

In order to reproduce in laboratory conditions the development of a natural phototrophic biofilm present on biodeteriorated stone surfaces, a natural green biofilm from Santa Clara-a-Velha Monastery, in Coimbra (central Portugal) was collected, its microbial community analyzed, and cultivated in liquid medium BG11 during three months. The last experimental step was the inoculation of this cultivated microbial community on lithic probes of similar composition in a laboratory chamber. The methodology used to monitor the composition of microbial community from environmental samples, in the cultural medium BG11 and on the stone probes is a culture-independent technique described below.

\subsection{Analysis of microbial communities}

Microbial communities DNA present in the natural green biofilm were extracted using the Nucleospin Food DNA Extraction Kit (Macherey-Nagel, Düren, Germany). The 16S and 18S rRNA genes were used for the identification of prokaryotes (bacteria and cyanobacteria) and eukaryotes (fungi and microalgae), respectively. Amplification of DNA was carried out by PCR in a BioRad iCycler iQ thermal cycler (BioRad, Hercules, CA). Bacterial 16S rRNA genes were amplified using the general primer pair 616F (5'-AGA GTT TGA TYM TGG CTC AG) (corresponding to position 27 of Escherichia coli 16S rRNA gene) (Zimmermann et al., 2005) and 907R (5'-CCC CGT CAA TTC ATT TGA GTTT) (corresponding to position 907 of E. coli 16S rRNA gene) (Schabereiter-Gurtner et al., 2001), comprising a denaturing step of $2 \mathrm{~min}$ at $95^{\circ} \mathrm{C}$, 35 cycles of denaturing $\left(95^{\circ} \mathrm{C}\right.$ for $\left.15 \mathrm{~s}\right)$, annealing $\left(55^{\circ} \mathrm{C}\right.$ for $\left.15 \mathrm{~s}\right)$ and elongation $\left(72{ }^{\circ} \mathrm{C}\right.$ for $2 \mathrm{~min}$ ), following a terminal elongation step of $10 \mathrm{~min}$ at $72{ }^{\circ} \mathrm{C}$. Cyanobacterial and chloroplasts $16 \mathrm{~S}$ rRNA genes were amplified using the primer pair Cya106F (5'-CGG ACG GGT GAG TAA CGC GTG A) and Cya781R (5'-GAC TAC TGG GGT ATC TAA TCC CWT T) and PCR conditions as described by Nübel et al. (1997). Eukaryotic $18 \mathrm{~S}$ rRNA genes were amplified with the primer pair EukA (5'-AAC CTG GTT GAT CCT GCC AGT) and EukB (5'-TGA TCC TTC TGC AGG TTC ACC TAC) (Diez et al., 2001). This amplification was carried out with a denaturing step of $2 \mathrm{~min}$ at $95^{\circ} \mathrm{C}, 35$ cycles of denaturing $\left(95{ }^{\circ} \mathrm{C}\right.$ for $\left.15 \mathrm{~s}\right)$, annealing $\left(50{ }^{\circ} \mathrm{C}\right.$ for $\left.12 \mathrm{~s}\right)$ and elongation $\left(72{ }^{\circ} \mathrm{C}\right.$ for $2 \mathrm{~min}$ ), following a terminal elongation step of $10 \mathrm{~min}$ at $72{ }^{\circ} \mathrm{C}$. TaKaRa ExTaq Polymerase (TaKaRa Shuzo Co., Otsu, JP) was used throughout this study.

Amplification products were used for two different protocols. The first analysis consisted in obtaining prokaryotic community fingerprints by Denaturing Gradient Gel Electrophoresis (DGGE) from all amplification products obtained using the primer pairs 616F-907R and Cya106F-Cya781R. A nested-PCR reaction was performed using the primer pair 341F-GC (5'-CC TAC GGG AGG CAG CAG, with a GC-rich tail added at its 5'-end) and 518R (5'-ATT ACC GCG GCT GCT GG), following the method described by Muyzer et al. (1993) and Gonzalez and Saiz-Jimenez (2004). Amplification conditions were as described for bacterial 16S rRNA genes with the exception of an extension step of only $30 \mathrm{~s}$. Four references strains were used as migration markers for comparison of DGGE patterns: Pseudomonas sp., E. coli, Paenibacillus sp. and Streptomyces sp.

The second analysis was aimed to obtain $16 \mathrm{~S}$ and $18 \mathrm{~S}$ rRNA gene clone libraries used for sequencing and identification. PCR products from the natural green biofilm and its liquid culture (samples AL1, 15 and 75), using 616F-907R, Cya106FCya781R and EukA-EukB primer pairs, were purified with the JetQuick PCR Purification Spin Kit (Genomed, Löhne, Germany) and cloned with the TOPO TA Cloning Kit (Invitrogen, Carlsbad, CA). Clone screening was carried out by DGGE as previously described (Gonzalez et al., 2003). The migration markers described above were used to locate the position of cloned fragments in the community fingerprints. A restriction digestion, using Hin6I and MspI enzymes, combined with electrophoresis in agarose was used for selecting fungal and algal clones. Plasmids were purified using the JetQuick Plasmid Purification Spin Kit (Genomed, Löhne, Germany) and sequenced by SECUGEN Sequencing Services (Madrid, Spain). Sequence data was edited using the software Chromas, version 1.45 (Technelysium, Tewantin, Australia). Homology searches with those sequences were performed using the Blast algorithm (Altschul et al., 1990) on the NCBI database 
(http://www.ncbi.nlm.nih.org/blast/). Nucleotide sequences obtained in this study have been deposited in the GenBank database under accession number from EU333004-EU333026.

The phototrophic microorganisms constituting the biofilm that colonizes Ançã limestone were also cultured, isolated and identified by light microscopy. The natural green biofilm samples (AL1, AL2, AL3) were inoculated on agar BG11 culture medium and incubated at $20^{\circ} \mathrm{C}$. Features of individual species were observed with an optical microscope equipped with a photographic camera. Taxonomic identification was carried out according to Bourrelly (1990) and Komárek and Anagnostidis (1999).

\subsection{Liquid culture enrichment}

The aim of this study was to simulate photosynthetic colonization on stone samples in the laboratory. BG11 culture medium was selected to promote the growth of these microorganisms (NORMAL 9/88). An aliquot of the natural biofilm sample was suspended in $15 \mathrm{ml}$ of sterile water and homogenised; the suspension was inoculated in 500-ml flask containing $400 \mathrm{ml}$ of liquid BG11 medium and incubated, during three months, at room temperature $\left(22^{\circ} \mathrm{C} \pm 2{ }^{\circ} \mathrm{C}\right)$ under natural light and with air circulation provided by an air pump. Every two weeks (days 15, 30, 45, 60, 75 and 90), $200 \mathrm{ml}$ of this culture was collected and stored at $-80^{\circ} \mathrm{C}$ for DGGE monitoring. This volume was replaced by fresh BG11 medium.

\subsection{Stone colonization experiment}

Quarry stone samples of Ançã limestone were used in the colonization experiment. Petrophysical characteristics of Ançã limestone, open porosity and capillarity, were previously determined and described in Miller et al. (2006). Six replicate stone probes (parallelepipeds of $4 \times 1 \times 4 \mathrm{~cm}$ ) were washed with sterile water and sterilized at $120{ }^{\circ} \mathrm{C}$ and $1 \mathrm{~atm}$, for $20 \mathrm{~min}$. After cooling, the probes were placed in a non-commercial

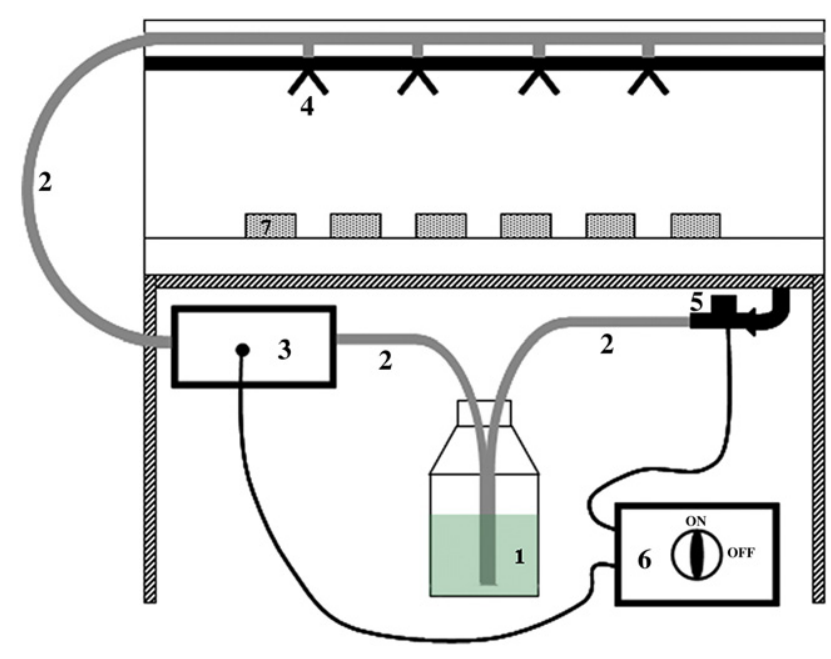

Fig. 1-Scheme of the laboratory chamber used to assess the ability of phototrophic communities to colonize stone probes: 1 - liquid culture; 2 - silicon tubing; 3 - automatic pumps; 4 - sprinklers; 5 - outlet valve device; 6 - control unit; 7 - stone probes.
Table 1 - Phylogenetic affiliations of eukaryotic

microorganisms derived from a natural green biofilm of Santa Clara-a-Velha Monastery

\begin{tabular}{|c|c|c|}
\hline $\begin{array}{l}\text { Accession } \\
\text { no. }^{\text {a }}\end{array}$ & Phylogenetic affiliation ${ }^{\mathrm{b}}$ & $\begin{array}{c}\text { Percent } \\
\text { similarity (\%) }\end{array}$ \\
\hline \multicolumn{3}{|l|}{ Algae } \\
\hline EU333011 & Chlorella vulgaris (X13688) & 99 \\
\hline EU333019 & Myrmecia bisecta (Z47209) & 97 \\
\hline EU333021 & Stichococcus sp. (AF513370) & 97 \\
\hline EU333025 & $\begin{array}{l}\text { Stichococcus bacillaris } \\
\text { (AY380557) }\end{array}$ & 99 \\
\hline EU333026 & Trebouxia sp. (Z21553) & 99 \\
\hline \multicolumn{3}{|l|}{ Fungi } \\
\hline EU333022 & Capnobotryella sp. (AJ972854) & 97 \\
\hline EU333023 & $\begin{array}{l}\text { Cladosporium cladosporioides } \\
\text { (DQ678004) }\end{array}$ & 99 \\
\hline EU333020 & $\begin{array}{l}\text { Cyphellophora laciniata } \\
\text { (AY342010) }\end{array}$ & 99 \\
\hline EU333024 & Phoma sp. (AB252869) & 100 \\
\hline
\end{tabular}

${ }^{\text {a }}$ Accession numbers of the sequences obtained in this study by cloning, are available at the NCBI database. Screening of clones was performed by restriction enzymatic digestion.

b Closest relatives obtained by comparison with the NCBI database. Accession numbers of the closest related database entries are given between brackets.

incubator system (Fig. 1). This laboratory chamber allows the inoculation of materials with an active growing microbial culture using an automatic irrigation system with a preestablished periodicity.

During the first two weeks of this experiment, the stone probes within the chamber were inoculated with the cultivated green biofilm, which passed through sprinkling rails and projected on the top of the stone probes for 5 min every $8 \mathrm{~h}$. After each sprinkling, the liquid deposited in the chamber was collected, recycled by a pump and sent towards the sprinkling rails. During the following two weeks, the stone probes were sprinkled with $1000 \times$ diluted BG11 medium for 5 min every $8 \mathrm{~h}$. After this period, the probes have been sprinkled for $5 \mathrm{~min}$ every $12 \mathrm{~h}$, in order to simulate outdoor environmental conditions.

The development of photosynthetic biofilms on stone probes was monitored by collecting, every two weeks, small samples of the biofilm covering the surface of two probes and analyzed by DGGE. The samples were obtained by scraping the biofilm into sterile tubes and immediately stored at $-80{ }^{\circ} \mathrm{C}$ until processing.

\section{Results and discussion}

\subsection{Identification of microbial communities of the natural green biofilm}

DNA-based molecular analysis of the green biofilm collected from Santa Clara-a-Velha Monastery revealed a complex microbial community. 16S and 18S rRNA genes libraries were used to identify the microbial components of the community. The number of sequenced clones during this study was 39 for prokaryotes and 22 for eukaryotes. 
The phototrophic microorganisms detected in this study were Chlorophyta and Cyanobacteria. Within Chlorophyta, Chlorella, Stichococcus, Trebouxia and Myrmecia were the genera identified. Among the Cyanobacteria, two genera were detected, Leptolyngbya and Pleurocapsa.

The bacteria identified belong to Bacteroidetes, Alphaproteobacteria, Actinobacteria and Verrucomicrobia. Fungi were also identified: Cyphellophora sp., Phoma sp., Cladosporium sp. and Capnobotryella sp. According to Wollenzien et al. (1995), the most abundant fungal genera on calcareous stone from monuments are Cladosporium, Penicillium, Trichoderma, Fusarium and Phoma. As reported (Burford et al., 2003), fungi play an important role in rock weathering and also in the biodeterioration of stone monuments as suggested by their presence in the studied samples. Using sequence analysis of 18S rRNA gene, high similarity $(\geq 99 \%)$ was found with NCBI database entries of the algae Chlorella vulgaris, Stichococcus bacillaris and Trebouxia sp., and the fungi Cladosporium cladosporioides, Cyphellophora laciniata and Phoma sp. (Table 1). Fig. 2 presents the phylogenetic affiliations of the phototrophic microorganisms and bacteria obtained from the natural green biofilm.

Most of the microorganisms detected in this study are very widespread on building stones according to several studies carried out by other authors in samples taken from stone monuments located in Europe (Ortega-Calvo et al., 1993; Tomaselli et al., 2000; Bellinzoni et al., 2003; Ascaso et al., 2004; Miller and Macedo, 2006).

For an enhanced assessment of the microbial communities present in samples from Santa Clara-a-Velha Monastery, DNA-based molecular analysis were complemented with cultivation procedures as recommended by Elsas et al. (1998) and Gonzalez and Saiz-Jimenez (2006). The cultivation approach allowed the assessment of the major phototrophic microorganisms present in the natural green biofilm samples. Enrichments in BG11 of these samples revealed the microalga genus Chlorella as well as the filamentous cyanobacterium Leptolyngbya sp. and the unicellular and nitrogen-fixing cyanobacterium Pleurocapsa sp. These results are in fair agreement with the data obtained by molecular techniques. All the three strains identified by microscopy were detected in the natural green biofilm corresponding to the strains analyzed by molecular techniques.

\subsection{Liquid culture monitoring}

The phototrophic biofilm growing in a flask containing BG11 medium was monitored during the three-month incubation period. Macroscopically, visible growth of the phototrophic

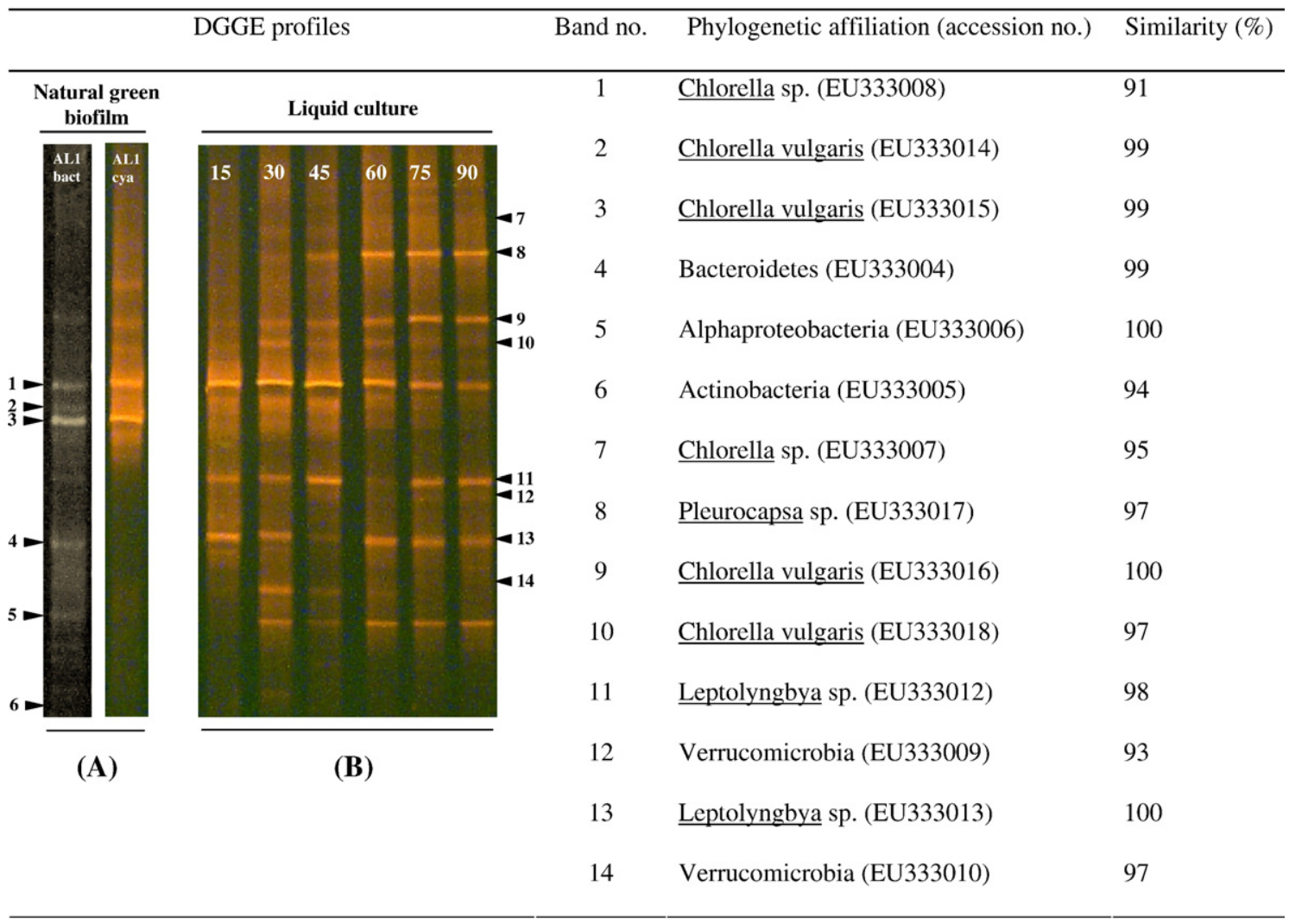

Fig. 2-DGGE patterns of 16S rRNA gene from a natural green biofilm collected from Santa Clara-a-Velha Monastery (A) and its liquid culture growing in BG11 medium over three months (B). Lanes AL1bact and AL1cya (A) correspond to DGGE patterns obtained after amplification using general bacterial primers and cyanobacteria-specific primers, respectively. Lanes 15, 30, 45, 60,75 , and 90 , corresponding to the sampling days of the liquid culture (B), were obtained after amplification using cyanobacteria-specific primers. Band numbers presented at the left side (bands 1 to 6) refer to clones obtained from samples AL1. Band numbers from the right side (bands 7 to 14) refer to clones obtained from samples 15 and 75 . The microorganisms in lanes 30, 4560 and 90 were identified according to their migration during DGGE analysis. 
community started one week after inoculation, presenting a brightly green colour. After one month, homogeneously distributed photosynthetic cells were observed showing a dense green colour, which remained constant until the end of the incubation period.

The development of the photosynthetic microbial community over the three-month period was monitored by DGGE to reach a steady state representing an establishment of the microbial components of the community. DGGE profiles showed the presence of up to ten distinguishable bands (Fig. 2). The microalga Chlorella (Fig. 2, bands 1-3, 9 and 10) was the predominant microorganism present in the cultured community, being detected in all samples along the incubation time as well as the cyanobacteria Leptolyngbya sp. (Fig. 2, bands 11 and 13) and Pleurocapsa sp. (Fig. 2, band 8). In addition, two bands corresponding to the Verrucomicrobia was detected in cyanobacteria-specific DGGE (Fig. 2, band 12 and 14). According to band migration during DGGE analysis, Bacteroidetes and Alphaproteobacteria (Fig. 2, bands 4 and 5, respectively) were present in the liquid culture profiles (Fig. 2, B). Band number 6 was mostly present in the original sample but was not significant in the liquid culture. The microbial development suggested that the culture reached a mature stage 45 days after inoculation, remaining constant. The DGGE profile of the liquid culture after 75 days incubation showed the highest similarity with the inoculum DGGE profile. This culture was chosen as a standardized phototrophic community adequate for the stone colonization experiment.

Molecular methods were very useful for this purpose, although microscopy techniques can also be used. DGGE analysis has become a useful and elegant method for profiling and monitoring bacterial communities (Schabereiter-Gurtner et al., 2001). By applying molecular methods we attempted to understand both the microorganisms growing easily on culture media and the uncultured microbial majority in the natural green biofilms. Microscopy allowed visualisation of spatial distribution but it was not easy to identify the phylogenetic lineage of its microbial components. Nevertheless, microscopy and molecular techniques are complementary for a complete assessment of the microbial communities.

\section{Incubation Photographic record}

time

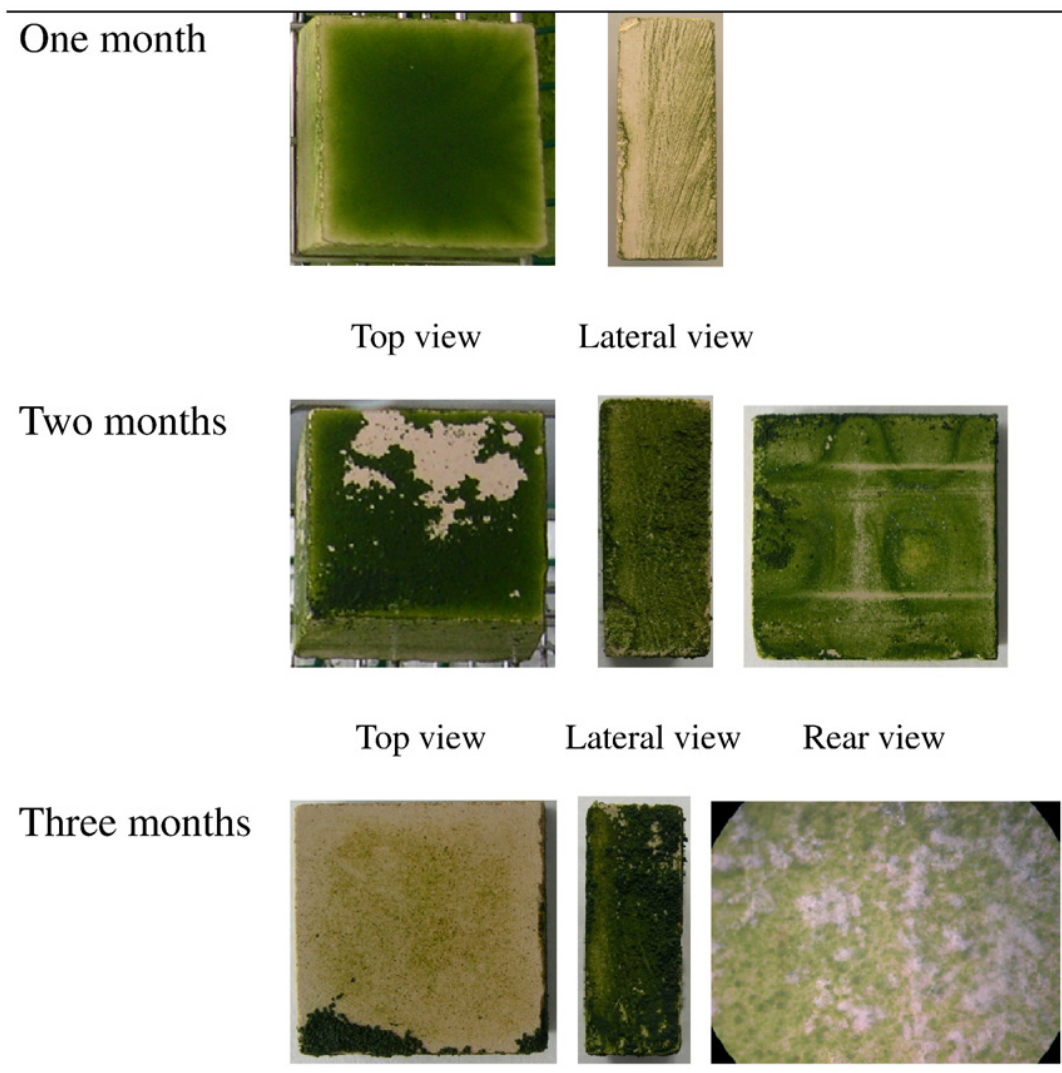

Top view Lateral view Rear side close view 


\subsection{Stone colonization experiment}

Ançã limestone samples were rapidly and highly colonized by phototrophic microorganisms. After one month of incubation, the stone probes presented a thick and homogeneously distributed green layer on the top face of the stones (Fig. 3). The colonization process also led to increased photosynthetic biomass on the vertical sides of the samples, showing preferential growth on rough areas.

At two months of exposure in the laboratory chamber, the setup had been exposed to more desiccating conditions (lower sprinkling frequency). One week later, the phototrophic layer covering the substrates started to detach from the top of the probes. The relative humidity fluctuation in the chamber might have been an essential factor in this detachment and this can also be a factor under natural conditions. Monuments experience large fluctuations in water circulation, including repeated desiccation and wetting, which was reproduced in the laboratory chamber. However, new re-colonization occurred on these stone surfaces, presenting a light green colour, which remained constant until the end of the experiment. In contrast, lateral and rear sides of the stone slabs were widely covered by photosynthetic biomass, showing dark green and dense biofilms (Fig. 3). This showed a similar pattern with that occurring in monuments where a great biomass growth is observed in humid areas protected from the rain. Guillitte and Dreesen (1995) in laboratory chamber studies also noticed that very rapidly the phototrophic biofilm covering the materials had cracked, forming partially curled-up scales, after decreasing sprinkling frequency. Detailed observations in different monuments suggest that the formation of an algal film developed on the stone surface depends strongly on the length of the period of wetness and the spatial orientation of the substratum. If conditions favour water evaporation, the algal layers may shrink as a result of desiccation, and remove stone grains which detach from the surface (Ortega-Calvo et al., 1991). If the stone remains wet long enough, the growth of the biofilm, production of organic matter and humification processes may produce protosoils, which may favour the settlement of mosses and higher plants (Ortega-Calvo et al., 1995).

After three months, it was observed that stone samples presented white colonies on the green biofilms covering the stone surfaces (Fig. 3). This colonization was attributed to fungal growth. The algal communities contributed through photosynthetic activity to a significant increase in the organic carbon content of the stone, favouring the growth of heterotrophic microorganisms. This result confirmed interactions between photosynthetic microorganisms (algae and cyanobacteria) and heterotrophic microorganisms (fungi and bacteria). For instance, Saiz-Jimenez et al. (1995) observed that heterotrophic microorganisms, within samples from Belgian monuments, can live either at the expense of the extracellular organic matter synthesized by living algae.

As judged by visual examination, the inoculated probes developed biofilms similar in appearance to those occurring on outdoor stone monuments. The major colonizers of the stone during the laboratory experiment were represented by the unicellular microalga Chlorella and the filamentous cyanobacterium Leptolyngbya (Fig. 4). However, one of the Chlorella sp. showed less ability to adapt to the changes of exposing conditions than Leptolyngbya sp., as revealed by decreasing of intensity of the corresponding band (Fig. 4). The nitrogen-fixing cyanobacterium Pleurocapsa was a minor representative in the laboratory stone colonization, suggesting that this microorganism was not a major colonizer of the stone surface. An unknown band was observed after 15 days of stone incubation which remained during all of the exposure period and likely corresponds to a microbial contamination.

The photosynthetic components of the natural green biofilm colonized the stone probes during the three months of incubation, and thereby demonstrated stability with time. Comparison of the microorganisms present in the environmental sampled biofilm, the liquid culture, and the colonizing community on stone probes showed great similarities and the major components were common to these three cases suggesting that the selected microbial assemblage dominated by phototrophs is a good inoculum for stone colonizations to be performed under laboratory conditions above all when climatic conditions are simulated.

Additionally, the bioreceptivity (Guillitte, 1995) of Ançã limestone to photosynthetic microorganisms was also studied. The stone colonization experiment showed that this lithotype is highly bioreceptive to phototrophic colonization. According to Albertano et al. (2000), carbonate rocks have a high risk of colonization by microorganisms and are extremely susceptible to cyanobacteria and algae. Previous reports proposed that a high porosity, linked to important open capillarity, allows the rapid development of colonizing organisms (Guillitte and Dreesen, 1995). The petrophysical characteristics of the lithotype used in this study, high porosity and capillary absorption, and its chemical composition were the keys to the establishment and development of the microbial biofilms (Miller et al., 2006). The high bioreceptivity presented by

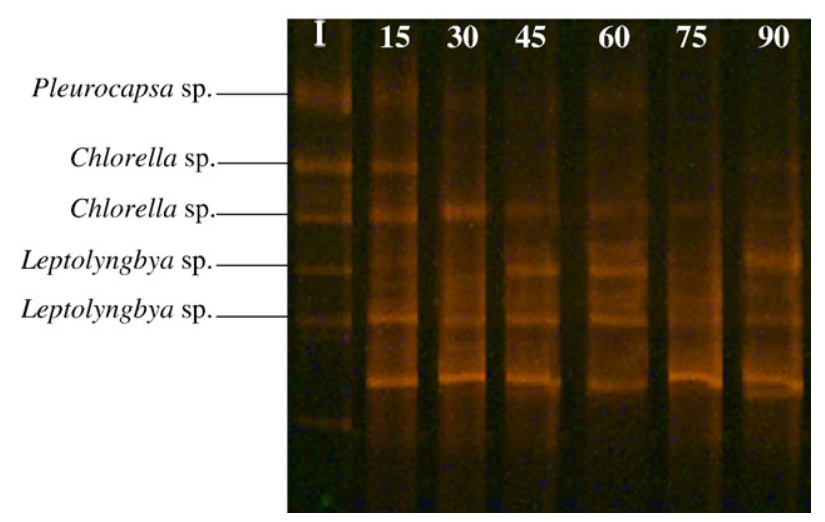

Fig. 4-DGGE fingerprints using cyanobacterial-specific primers from samples of artificially colonizing biofilms on Ançã limestone incubated in a laboratory chamber over three months $(15,30,45,60,75$, and 90 days). Lane I corresponds to the inoculum used to start the colonization process of these stone probes. Lanes 15 to 90 represent the microbial communities' profiles of this stone colonization experiment at the indicated sampling time. 
this limestone may induce severe biodeterioration on the substrate, which should be assessed by using environmental scanning electron microscopy and confocal scanning laser microscopy (Roldán et al., 2006). Further work complementing molecular methods and microscopy will contribute to decipher the actual role and effects of specific microbial cells on stone monuments. One of the drawbacks of molecular methods is that no morphological and physiological information is extracted. Since microbial ecology involves the study of the relationships between microorganisms and their environment, microscopy techniques are necessary to study the interaction between the microbial communities and the mineral substrate, including both taxonomical and morphological characterizations.

\section{Conclusions}

The microbial community obtained during this study represents a complexity comparable to natural communities and the procedure using a laboratory chamber was able to reproduce colonization of stone in the laboratory. This study shows that reproducible colonization experiments under accelerated laboratory conditions can be performed using complex microbial communities, presenting the advantage of simulating the existence of competition and/or synergy between colonizing microorganisms.

\section{Acknowledgments}

This is a paper from the project CONSOLIDER CSD2007-00058. This work was also supported by the Ministério da Ciência, Tecnologia e Ensino Superior, Portugal, with a doctoral grant (SFRH/BD/21481/2005). LL acknowledges support from the Consejo Superior de Investigaciones Científicas, project 200740/011. The facilities provided by Santa Clara-a-Velha Monastery are gratefully acknowledged.

\section{R E F E R E N C E S}

Aires-Barros L, Basto MJ, Charola AE. Black crusts: "fossil" and modern. A comparison from two case studies in Coimbra Monuments (Central Portugal). Int Z Bauinstandsetzen Baudenkmalpflege 2000;6:63-72.

Albertano P, Bruno L, Bellezza S, Paradossi G. Polysaccharides as a key step in stone bio-erosion. In: Fassina V, editor. Ninth Int. Cong. deterioration and conservation of stone vol. 1. Venice: Elsevier; 2000. p. 425-32.

Altschul SF, Gish W, Miller W, Myers EW, Lipman DJ. Basic local alignment search tool. J Mol Biol 1990;215:403-10.

Ascaso MA, del Cura G, de Los Ríos A. Microbial biofilms on carbonate rocks from a quarry and monuments in Novelda (Alicante, Spain). In: Clair S, Seaward M, editors. Biodeterioration of stone surfaces. Dordrecht: Kluwer Academic Publishers; 2004. p. 79-98.

Bellinzoni AM, Caneva G, Ricci S. Ecological trends in travertine colonization by pioneer algae and plant communities. Int Biodeterior Biodegrad 2003;51:203-10.

Bourrelly P. Les algues d'eau douce - Initiation à la systématique, I: Les Algues Vertes. Paris: N. Boubée; 1990. 572 pp.
Burford EP, Kierans M, Gadd GM. Geomycology: fungi in mineral substrata. Mycologist 2003;17:98-107.

Ciferri $\mathrm{O}$. The role of microorganisms in the degradation of cultural heritage. Rev Conserv 2002;3:35-45.

Crispim CA, Gaylarde CC. Cyanobacteria and biodeterioration of cultural heritage: a review. Microb Ecol 2005;49:1-9.

Diez B, Pedros-Alio C, Marsh TL, Massana R. Application of denaturing gradient gel electrophoresis (DGGE) to study the diversity of marine picoeukaryotic assemblages and comparison of DGGE with other molecular techniques. Appl Environ Microb 2001;67:2942-51.

Dionísio, A. A Pedra de Ançã: características minero-químicas e petrofísicas. MscE Thesis, Universidade Técnica de Lisboa, Instituto Superior Técnico 1997, Portugal.

Elsas JD, Duarte GF, Rosado AS, Smalla K. Microbiological and molecular biological methods for monitoring microbial inoculants and their effects in the soil environmental. J Microbiol Methods 1998;32:133-54.

Gonzalez JM, Saiz-Jimenez C. Microbial activity in biodeteriorated monuments as studied by denaturing gradient gel electrophoresis. J Sep Sci 2004;27:174-80.

Gonzalez JM, Saiz-Jimenez C. Current advances in the molecular characterization of microbial communities on cultural heritage. In: Fort R, Alvarez de Buergo M, Gomez-Heras M, Vazquez-Calvo C, editors. First Int Conf heritage, weathering and conservation. London: Taylor and Francis; 2006. p. 343-8.

Gonzalez JM, Ortiz-Martinez A, Gonzalez-delValle MA, Laiz L, Saiz-Jimenez C. An efficient strategy for screening large cloned libraries of amplified 16S rDNA sequences from complex environmental communities. J Microbiol Methods 2003;55:459-63.

Guillitte O. Bioreceptivity: a new concept for building ecology studies. Sci Total Environ 1995;167:215-20.

Guillitte O, Dreesen R. Laboratory chamber studies and petrographical analysis as bioreceptivity assessment tools of building materials. Sci Total Environ 1995;167:365-74.

Herrera LK, Arroyave C, Guiamet P, Gómez de Saravia S, Videla H. Biodeterioration of peridotite and other constructional materials in a building of the Colombian cultural heritage. Int Biodeter Biodegr 2004;54:135-41.

Komárek J, Anagnostidis K, Cyanoprocaryota I. In: Ettl H, Gerloff J, Heynig H, Mollenhauer D, editors. Süßwasserflora von Mitteleuropa, Band 19/1. Paris: Gustav Fischer Verlag; 1999. $548 \mathrm{pp}$.

Miller A, Macedo MF. Mapping and characterization of a green biofilm inside of Vilar de Frades Church (Portugal). In: Fort R, Alvarez de Buergo M, Gomez-Heras M, Vazquez-Calvo C, editors. First Int Conf heritage, weathering and conservation. London: Taylor and Francis; 2006. p. 329-35.

Miller A, Dionísio A, Macedo MF. Primary bioreceptivity: a comparative study of different Portuguese lithotypes. Int Biodeterior Biodegrad 2006;57:136-42.

Monte M. Oxalate film formation on marble caused by fungus. J Cult Herit 2003;4:255-8.

Muyzer G, de Waal EC, Uitterlinden AG. Profiling of complex microbial populations by denaturing gradient gel electrophoresis analysis of polymerase chain reaction-amplified genes coding for 16S rRNA. Appl Environ Microb 1993;59:695-700.

NORMAL 9/88. Microflora autotrofa ed eterotrofa: tecniche di isolamento in coltura. Raccomandazioni Normal, Doc. Normal 9/88, Istituto Centrale del Restauro-Commissione Normal (ICRCNR), Rome: ICR-CNR; 1998. 26 pp.

Nübel U, Garcia-Pichel F, Muyzer G. PCR primers to amplify $16 \mathrm{~S}$ rRNA genes from cyanobacteria. Appl Environ Microbiol 1997;63:3327-32.

Ortega-Calvo JJ, Hernandez-Marine M, Saiz-Jimenez C. Mechanical deterioration of building stones by cyanobacteria and algae. In: Rossmoore HW, editor. Biodeterioration and biodegradation 8. London: Elsevier; 1991. p. 392-4. 
Ortega-Calvo JJ, Sanchez-Castillo PM, Hernandez-Marine M, Saiz-Jimenez C. Isolation and characterization of epilithic chlorophyta and cyanobacteria from two Spanish cathedrals (Salamanca and Toledo). Nova Hedwig 1993;57:239-53.

Ortega-Calvo JJ, Ariño X, Hernandez-Marine M, Saiz-Jimenez C. Factors affecting the weathering and colonization of monuments by phototrophic microorganisms. Sci Total Environ 1995;167:329-41.

Prieto B, Silva B. Estimation of the potential bioreceptivity of granitic rocks from their intrinsic properties. Int Biodeterior Biodegrad 2005;56:206-15.

Roldán M, Oliva F, Gónzalez del Valle MA, Saiz-Jimenez C, Hernández-Mariné M. Does green light influence the fluorescence properties and structure of phototrophic biofilms? Appl Environ Microbiol 2006;72:3026-31.

Saiz-Jimenez C, Ariño X, Ortega-Calvo JJ. Mechanisms of stone biodeterioration by photosynthesis-based epilithic biofilms. In: De Cleene $\mathrm{M}$, editor. Interactive physical weathering and bioreceptivity study on building stones, monitored by Computerized X-Ray Tomography (CT) as a potential non-destructive research tool. Protection and Conservation of the European
Cultural Heritage Research Report $\mathrm{N}^{\circ}$ 2. European Commission, Brussels: Directorate-General XII; 1995, pp. 25-62.

Sand W. Microbial mechanisms of deterioration of inorganic substrates - a general mechanistic overview. Int Biodeterior Biodegrad 1997;40:183-90.

Schabereiter-Gurtner C, Piñar G, Lubitz W, Rölleke S. An advanced molecular strategy to identify bacterial communities on art objects. J Microbiol Methods 2001;45:77-87.

Tiano P, Accolla P, Tomaselli L. Phototrophic biodeteriogens on lithoid surfaces: an ecological study. Microb Ecol 1995;29:299-309.

Tomaselli L, Lamenti G, Bosco M, Tiano P. Biodiversity of photosynthetic micro-organisms dwelling on stone monuments. Int Biodeterior Biodegrad 2000;46:251-8.

Wollenzien U, deHoog GS, Krumbein WE, Urzi C. On the isolation of microcolonial fungi occurring on and in marble and other calcareous rocks. Sci Total Environ 1995;167:287-94.

Zimmermann J, Gonzalez JM, Saiz-Jimenez C. Detection and phylogenetic relationships of highly diverse uncultured acidobacterial communities in Altamira Cave using 23S rRNA sequence analyses. Geomicrobiol J 2005;22:379-88. 